\title{
Heat-Resistant Foam Concrete on the Basis of Two-Component Binder
}

\author{
S. N. Leonovich ${ }^{1)}$, D. V. Sviridov' ${ }^{2)}$ A. L. Belanovich ${ }^{2)}$, V. P. Savenko ${ }^{2)}$, S. A. Karpushenkov ${ }^{2)}$ \\ ${ }^{1)}$ Belarusian National Technical University (Minsk, Republic of Belarus), \\ ${ }^{2)}$ Belarusian State University (Minsk, Republic of Belarus) \\ (C) Белорусский национальный технический университет, 2019 \\ Belarusian National Technical University, 2019
}

\begin{abstract}
The composition of dry mix on the basis of two-component cementing agent (aluminous cement and clay of the "Kustikha" field), mineral additives (a metakaolin, the RSAM sulfoaluminate modifier, waste of basalt fiber), Ufapore foamer and the accelerating and plasticizing "Citrate- $T$ " additive is developed. When mixing "Citrate- $T$ " additive with water at Water/Solid $=0.45-0.70$, the subsequent mechanical binder and hardening of a foam mass heat-resistant foam concretes with a density of 300-650 kg/m $\mathrm{m}^{3}$ are formed (depending on Water/Solid value). Foam concretes have strength on compression of 0.2-2.5 MPa before warming up when their initial strength depends on processes of hydration curing of aluminous cement that provides fixation of their porous structure. After annealing at $1000^{\circ} \mathrm{C}$ foam concretes have final strength of $0.3-3.2 \mathrm{MPa}$ due to processes of solid-phase agglomeration of clay with other components of dry mix at their heating. Foam concretes after annealing unlike foam concretes on the basis of a Portland cement and aluminous cement have big strength. Introduction of the accelerating and plasticizing "Citrate-T" additive into composition of the dry mix leads to an increase of rheological properties in expanded foam mass and time reduction of its drying and curing. It has been established that an essential role is played by the relation Water/Solid: at increase in the relation Water/Solid (with 0.45 to 0.70 ) occurs increase in volume of foam mass after a mechanical binder, and also heterogeneity of pores and their sizes increases that leads to reduction of density of foam concretes and strength on compression.
\end{abstract}

Keywords: dry mix, heat-resistant foam concrete, mineral additives, foamer, accelerating and plasticizing additive

For citation: Leonovich S. N., Sviridov D. V., Belanovich A. L., Savenko V. P., Karpushenkov S. A. (2019). Heat-Resistant Foam Concrete on the Basis of Two-Component Binder. Science and Technique. 18 (2), 121-126. https://doi.org/10. 21122/2227-1031-2019-18-2-121-126

\section{Жаростойкий пенобетон на основе двухкомпонентного вяжущего}

\author{
Докт. техн. наук, проф. С. Н. Леонович ${ }^{1)}$, докт. хим. наук, проф. Д. В. Свиридов²), \\ канд. хим. наук А. Л. Беланович ${ }^{2)}$, В. П. Савенко ${ }^{2)}$, канд. хим. наук С. А. Карпушенков

\footnotetext{
${ }^{1)}$ Белорусский национальный технический университет (Минск, Республика Беларусь),

${ }^{2)}$ Белорусский государственный университет (Минск, Республика Беларусь)
}

Реферат. Разработан состав сухой смеси на основе двухкомпонентного вяжущего (глиноземистого цемента и глины месторождения «Кустиха»), минеральных добавок (метакаолин, сульфоалюминатный модификатор РСАМ, отходы базальтового волокна), пенообразователя Ufapore и ускоряющей и пластифицирующей добавки «Цитрат-Т», при затворении которой водой при водотвердом отношении 0,45-0,70, последующем механическом вспучивании и отверждении пеномассы формируются жаростойкие пенобетоны плотностью 300-650 кг/м ${ }^{3}$ (в зависимости от водотвердого отношения) и прочностью на сжатие 0,2-2,5 МПа до прогрева. Жаростойкие пенобетоны приобретают начальную прочность за счет процессов гидратационного твердения глиноземистого цемента, обеспечивают фиксирование пористой структуры пенобетонов и набирают конечную прочность $0,3-3,2$ МПа после отжига при $1000^{\circ} \mathrm{C}$ за счет процессов твердофазного спекания глины с другими компонентами сухой смеси при их нагревании до $1000{ }^{\circ} \mathrm{C}$, которые в отличие от пенобетонов на основе портландцемента и глиноземистого цемента не снижают, а наоборот,

\section{Адрес для переписки}

Леонович Сергей Николаевич

Белорусский национальный технический университет просп. Независимости, 150,

220014, г. Минск, Республика Беларусь

Тел.: +375 17 265-96-76

leonovichsn@tut.by

\author{
Address for correspondence \\ Leonovich Sergey N. \\ Belarusian National Technical University \\ 150 Nezavisimosty Ave., \\ 220014, Minsk, Republic of Belarus \\ Tel.: +375 17 265-96-76 \\ leonovichsn@tut.by
}


увеличивают свою прочность. Введение в состав сухой смеси ускоряющей и пластифицирующей добавки «Цитрат-Т» приводит к повышению реологических свойств вспененной пеномассы и сокращению времени ее схватывания и твердения. Установлена существенная роль водотвердого отношения при получении пенобетонов: с повышением водотвердого отношения с 0,45 до 0,70 увеличиваются объем пеномассы после вспучивания, неоднородность пор и их размеры, что приводит к уменьшению плотности пенобетонов и прочности на сжатие.

Ключевые слова: сухая смесь, жаростойкий пенобетон, минеральные добавки, пенообразователь, ускоряющая и пластифицирующая добавка

Для цитирования: Жаростойкий пенобетон на основе двухкомпонентного вяжущего / С. Н. Леонович [и др.] // Наука и техника. 2019. Т. 18, № 2. С. 121-126. https://doi.org/10.21122/2227-1031-2019-18-2-121-126

One of relevant materials research tasks consists in creation of effective and inexpensive heatinsulating materials for improvement of the designs of a heat-shielding working in the conditions of high-temperature heating.

Foam concrete, undoubtedly, one of the most perspective and attractive construction materials. At low prime cost, this environmentally friendly material has high heat-insulating parameters, low density, and fire resistance and is one of effective heat-resistant materials.

Aluminous and high-aluminous cements widely use at production modern the furring of fireresistant compositions $[1,2]$. These cements are distinguished by a combination of the properties necessary for production of heat-resistant cellular materials: the high initial speed of curing promoting obtaining qualitative porous structure, fire resistance and high durability. However, use of aluminous cements in compositions of cellular concrete which are made on foamy technology is accompanied by a number of problems: aluminous cements considerably reduce stability of foam in the course of receiving foam-concrete mix, concrete on aluminous cements are characterized by considerable decrease in strength in the range of working temperatures of the majority of industrial furnaces [2].

The technology and properties gazo- and foam concretes are almost identical. The main lack of foam concretes is use of foaming agents, the majority of whom are strong delay mechanisms of curing of cements, especially at a stage of set of plastic strength. However, foam concretes are distinguished by softer and uniform porosity and, with other things being equal, higher strength [3].

Recently there were various prescription compositions and various additives, processing methods and the equipment allowing improving production of foam-concrete products [4]. One of the perspective directions of increase in technological efficiency of foam concretes is receiving dry mixes for their production [5].

The analysis of the current state of production of dry construction mixes shows that in their various nomenclatures there are practically no mineral distending composite materials. International and domestic experience of use of dry mixes in construction confirms their high efficiency and advantages in comparison with traditional methods of work. The appeal of dry mixes to consumers is that they are almost ready to the use, are conveniently packaged and at the correct operation the long time is kept by the properties. In this regard, the researches directed to development of technology of receiving dry mixes for production of heatresistant foam concretes and studying of their properties are relevant.

The purpose of this work is development of composition of dry mix for production of heatresistant foam concretes with use two-component knitting.

For achievement of a goal it was necessary to solve the following problems: to study physical and chemical processes of structurization at application two-component knitting when receiving heat-resistant foam concretes, to investigate influence of solid foaming agent and mineral additives on density, structure and strength characteristics of foam concretes when heating to $1000{ }^{\circ} \mathrm{C}$, to establish their optimum concentration, to develop composition of dry mix.

For a basis for development of dry mix for receiving heat-resistant foam concrete used twocomponent knitting - aluminous GTs-40 cement and the clay from the field of Kustikh (Gomel region) which is previously dried up at $150{ }^{\circ} \mathrm{C}$ and crushed in a spherical mill till the rest on a grid No 0.25 .

In the course of performance of experimental work it is established that unlike the traditional foam concretes (in particular, on the basis of the 
portlandtcement and aluminous cement) losing durability already at a temperature of $600-800{ }^{\circ} \mathrm{C}$, foam concretes on the basis of two-component knitting get initial strength due to the processes of hydration curing of aluminous cement providing fixation of porous structure of foam concretes and gaining final strength due to processes of solidphase agglomeration of clay and waste of fireresistant materials (chamotte) at their heating which don't reduce the strength, and, on the contrary, increase.

As aluminous cement consists, generally of the low-main aluminates of calcium, at hydration eventually, hydro aluminates are enriched with oxide of calcium and the additional amount of hydroxide of aluminum is distinguished. At the same time changes crystals of hydro aluminates and hydroxide of aluminum crystallizes. Processes of recrystallization of hydro aluminates proceed quicker, than calcium hydro silicates in a portlandtcement. Gels of aluminates of calcium are characterized by obviously expressed thixotropy and show properties the elastic-plastic of bodies that is very important in technology of foam concretes. The foam-forming ability and stability of the received foams is also influenced by change $\mathrm{pH}$ the water phase and ions which are formed because of hydration of cement [6].

Foam concrete was received by mechanical hashing $(300 \mathrm{rpm})$ of dry mix with water at W/S the relation $0.45-0.70$ within $5 \mathrm{~min}$ and the subsequent swelling up cement mix with the help of the mixer (2000 rpm) within $2 \mathrm{~min}$ and hardening of blown-out weight.

It is established that the greatest stability the made foam mass when using solid powdery Ufapore foaming agent at its concentration has of $0.5-1.0 \%$. Stability of the made foam mass in time remains within 20-30 $\mathrm{min}$, and then its draft with reduction of volume by $30-35 \%$ begins.

It is known [7] that the more extent of hydration of aluminous cement for the same period, the is higher supersaturation of a gel liquid phase. The last allows to influence effectively not only the speed of curing of cement mortar, but also process of management of structurization and to support constant conditions of formation of a liquid phase for the entire period of growth of structure. It can be reached at the expense of the additives entered into structure of the cement test, i. e. substances increasing interaction of cement clinker with water or promoting increase in speed of a conclusion of some products of hydration from the environment of interaction of cement with water.

To such additives as it is established in works $[8,9]$, it is necessary to carry citrate of sodium which provides the high initial strength of destruction of brick materials of cement and at the same time promotes creation of liquid gel phase. Speed of saturation of the last is defined not only by concentration of citrate of sodium, but also a amount of water. Besides, the citrate of sodium which is present at cement hydration process provides formation in a gel phase of ultra-small particles of hydro aluminates which are partially or completely in a X-ray amorphous form. Amorphicity of hydrates is followed by increase in alkalinity of the environment and their dispersion. The last leads to essential hardening of a cement stone.

For increase in stability of of foam mass in time entered Citrate-T additive on the basis of sodium citrate in number of $1.7 \%$ [8] which allows to improve rheological properties of the made foam mix into composition of dry mix: to increase her mobility (dislocation a minicone in the presence of additive makes $60-80 \mathrm{~mm}$, while without her $40-45 \mathrm{~mm}$ ), to increase stability of a foam mass and to accelerate secure time $(5 \mathrm{~h})$ and $(10 \mathrm{~h})$ in comparison with foam concrete without Citrate-T additive ( $24 \mathrm{~h}$ and more).

For the purpose of increase in thermal firmness of foam concretes at the subsequent their hightemperature heating and reductions of aluminous cement as a part of dry mix added fine clay and waste of fire-resistant materials (chamotte). As clay component of two-component knitting clays from various fields of Republic of Belarus have been tested (Gaydukovka, Osetki, Kustikh, Lukoml). For establishment of a possibility of use of clay of a certain field pilot studies according to her influence on stability of foam mass, terms of curing and property of foam concretes at their heating to $1000{ }^{\circ} \mathrm{C}$ have been conducted. Researches have shown that when using fine clay of the field of Kustikh (the chemical composition, mas. \%: $\mathrm{SiO}_{2}-65 ; \mathrm{Al}_{2} \mathrm{O}_{3}-12.58 ; \mathrm{Fe}_{3} \mathrm{O}_{4}-4.4 ; \mathrm{TiO}_{2}-0.78 ;$ $\mathrm{CaO}$ - 4.48; $\mathrm{MgO}-1.0 ; \mathrm{K}_{2} \mathrm{O}-1.85 ; \mathrm{Na}_{2} \mathrm{O}-0.37$; $\mathrm{SO}_{3}-0.17$ [10]) the made foam mass differs in bigger stability and uniformity of a small time, than when using clays of other fields. 
The analysis of experimental data has shown that further improvement of fire properties of foam concretes can be reached due to use of the filler received by crushing of waste of chamotte. Optimum content of aluminous cement, clay of Kustikh and waste of chamotte as a part of dry mix is established. The structures containing GTs-40 in number of 25-30\%, clays of 25-30\% and chamotte of $25-30 \%$ also are preferable. Such structures are characterized by an optimum combination of compressive strength of foam concretes after natural curing (2.0-2.5 MPa) and after their heating to $1000{ }^{\circ} \mathrm{C}(3.0-3.2)$.

As is well-known [6], aluminous cement distinguishes rapid growth of strength, especially in initial terms of curing of a cement stone. It is necessary to refer decrease in strength at long curing to his shortcomings. Recrystallization of hexagonal hydro aluminates in a cubic form is the reason of falling of strength of a cement stone. It is established [11] that the great influence on recrystallization of hydro aluminates of calcium from a hexagonal form in cubic is exerted by super saturation on SAO of steam liquid of a cement stone. The research of process of hydration of aluminous cements with additive of a met kaolin has shown increase in speed of hydration of aluminous cement and lack of recrystallization of hydro aluminates of calcium [12]. Introduction of a met kaolin to aluminous cement leads to stabilization of hexagonal hydro aluminates of calcium at long curing of aluminous cement that has allowed recommending composite structure (aluminous cement with additive of $5 \%$ of met kaolin) for preparation of dry mix.

Also it has been established that at a blown-out of dry mix on the basis of aluminous cement, the clay of Kustikh, chamotte and a met kaolin containing Citrate- $\mathrm{T}$ additive and Ufapore foaming agent at $\mathrm{W} / \mathrm{S}$ the relation $0.45-0.70$ foam concretes with a density of $300-600 \mathrm{~kg} / \mathrm{m}^{3}$ when drying which in 5-10 days are formed shrinkable cracks due to formation of a large number of the ettringit for unit of volume of foam concrete are formed [6]. Decrease in number of the ettringit can be reached due to calcium hydroxide binding in the course of initial structurization of foam concrete in almost insoluble connections.

Data on use as a part of cellular and concrete mixes of the RSAM additive representing the extending sulfoalyuminatny modifier, which gives the chance to give to cement such properties as ensuring compensation of shrinkable deformations and increase of strength, are provided in works $[13,14]$.

It is established that RSAM additive has the extending effect and in foam concrete on the basis of two-component knitting - aluminous cement and clay of Kustikh that allows to use it for compensation of shrinkage in the presence of Citrate- $\mathrm{T}$ additive.

Boundary concentration of RSAM in number of $15 \%$ of the mass of aluminous cement which introduction to dry mix provides manifestation of the expanding effect when receiving heat-resistant foam concrete is defined.

Expansion of field of effective use of heatresistant foam concretes is possible due to disperse reinforcing by fibers of mineral origin. Addition in foam concrete of a fiber can't change either density, or heat conductivity of material. However, it can affect strength indicators. One of the main shortcomings of foam concrete is his high fragility. Besides, shrinkable deformations when heating are characteristic of heat-resistant foam concretes that leads to emergence in them of the cracks bringing then to destruction of all material. For improvement of properties of heat-resistant foam concretes expediently disperse reinforcing by mineral fibers, in particular, basalt. Basalt fiber is a by-product of receiving a basalt roving. In works $[15,16]$ it is established that on border of foam-cement weight and the basalt fiber which is in an amorphous state there is a hemo-sorption interaction with the advent of the additional new growths relating to the low-main hydro silicates of calcium. On the surface of thin basalt fibers in places of mechanical defects the centers of crystallization with formation of network of the hexagonal plates and needle crystals which are growing together with spherical grains of cement system in addition are created strengthening effects of fibers as disperse fittings.

Having considered efficiency of the used components of dry mix for receiving heat-resistant foam concretes, pilot study on optimization of composition of dry mix, establishment of optimum concentration of components and influence of structure on physical and chemical properties of foam mass and foam concrete has been conducted. As it has been established, optimum concentration of 
mineral additives as a part of dry mix on the basis of aluminous cement, clay of Kustikh and chamotte at their ratio 1:1:1 are, mas. \%: a met kaolin - 5, RSAM - 5, basalt fiber - 3.2, Citrate-T additive -1.7 and Ufapore 0.5 foaming agent. From such composition of dry mix it is possible to receive heat-resistant foam concrete without emergence of shrinkable cracks with a density of $300-650 \mathrm{~kg} / \mathrm{m}^{3}$ depending on $\mathrm{W} / \mathrm{S}$ of the relation (0.45-0.70) and compressive strength of $0.2-2.5 \mathrm{MPa}$ at natural hardening and $0.3-3.2 \mathrm{MPa}$ after warming up at $1000{ }^{\circ} \mathrm{C}$. Foam concrete at natural hardening has gray color, and after warming up at $1000{ }^{\circ} \mathrm{C}$ due to solid-phase agglomeration of clay with components of dry mix - redbrown (fig. 1).

a

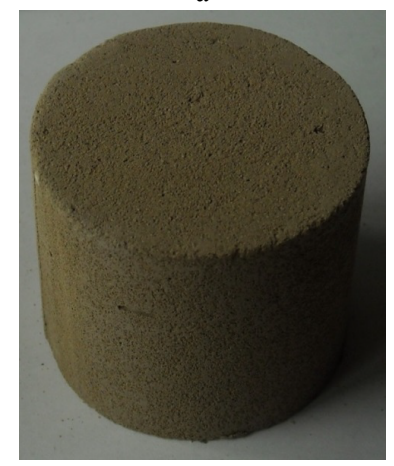

Fig. 1. Samples of heat-resistant foam concrete after drying at $110^{\circ} \mathrm{C}$ (a) and after annealing at $1000^{\circ} \mathrm{C}$ (b)

When determining W/S of the relation it is important to consider that one part of water is necessary for formation of foam and another - for hydration knitting both dissolution of solid additives, and the over expenditure or the shortage of water substantially worsens structure of foam concrete. Reduction of W/S of the relation allows increasing density and strength of foam concretes, but at the same time rheological properties of foam mass worsen. At increase in W/S of the relation, the draft of foam mass and reduction of density and strength of foam concretes is observed. It is established that the range of optimum W/S of the relation is rather narrow. At W/S values of the relation less than 0.45 process of formation of foamconcrete mix can't be carried out. If W/S exceeds the relation 0.70 , the uniformity of a time of foamconcrete mix (the sizes a bubble fluctuate from 0.1 to $3.0 \mathrm{~mm}$ ) decreases, foam mass volume after swelling up increases by $30-40 \%$ and considera- bly foam concrete density up to $250-300 \mathrm{~kg} / \mathrm{m}^{3}$ and its strength $(0.2-0.3 \mathrm{MPa})$ decreases.

Apparently from 2 photos of morphology of a surface of chips of foam concrete provided on fig. 2 after natural curing within 28 days (a) and $\mathrm{W} / \mathrm{S}$ of the relation which are warmed up at $1000{ }^{\circ} \mathrm{C}$ (b) with increase from 0.45 to 0.70 heterogeneity of a time and their sizes increases and shrinkable cracks even after warming up aren't observed at $1000{ }^{\circ} \mathrm{C}$.

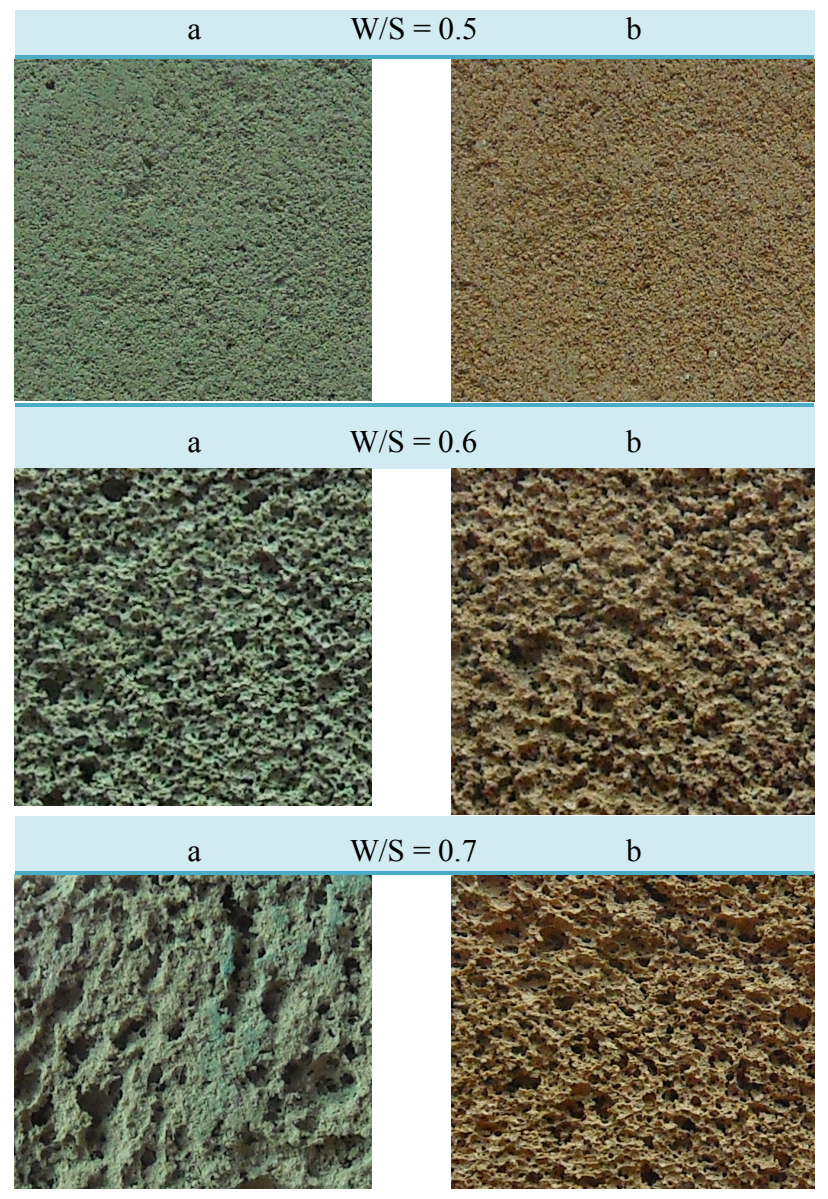

Fig. 2. Morphology of a surface of chips of foam concretes after drying at $110^{\circ} \mathrm{C}$ (a) and W/S which are warmed up at $1000^{\circ} \mathrm{C}($ b) depending on a ratio (increase $\times 8$ )

\section{CONCLUSION}

As a result of the carried-out work the composition of dry mix on the basis of two-component knitting (aluminous cement and clay of Kustikh), mineral additives (a met kaolin, the RSAM sulfoalyuminatny modifier, waste of basalt fiber), Ufapore foaming agent and the accelerating and plasticizing Citrate- $\mathrm{T}$ additive water at W/S the relation $0.45-0.70$, the subsequent mechanical 
hardening of foam mass forms the heat-resistant foam concretes with a density of $300-650 \mathrm{~kg} / \mathrm{m}^{3}$ and compressive strength of $0.2-3.2 \mathrm{MPa}$ getting initial strength due to processes of hydration curing of aluminous cement and gaining final strength due to processes of solid-phase agglomeration of clay of Kustikh with other components of dry mix at their heating to $1000{ }^{\circ} \mathrm{C}$ which unlike foam concretes on the basis of the portlandcement and aluminous cement don't reduce the strength, and, on the contrary, is developed increase.

\section{REFERENCES}

1. Gorlov Yu. P., Eremin N. F., Sedunov B. U. (1976) FireResistant and Heat-Insulating Materials. Moscow, Stroiizdat Publ. 192 (in Russian).

2. Gorin V. M., Suhov V. Yu., Nehaev P. F., Hlistov A. I., Riyazov R. T. (2003) Light Heat-Resistant Concrete of Cellular Structure. Stroitel'nye Materialy [Construction Materials], (8), 17-19 (in Russian).

3. Gorlov Yu. P., Merkin A. P., Ustenko A. A. (1980) Technology of Heat-Insulating Materials. Moscow, Stroiizdat Publ. 316 (in Russian).

4. Yudin A. N., Tkachenko G. A., Izmailova E. V. (2001) About a Technique of Composition Design of Not Autoclave Foam Concretes with Single-Stage Preparation of Cellular Mix. Izvestiya Vuzov. Stroitel'stvo $=$ News of Higher Education Institutions. Construction, (7), 21-25 (in Russian).

5. Kroichuk L. A. (2000) Experience of Production and Use Dry Cement Mixes Abroad. Stroitel'nye Materialy [Construction Materials], (9), 16-17 (in Russian).

6. Kuznetsova T. V. (1986) The Aluminous and Sulfoaluminous Cements. Moscow, Stroiizdat Publ. 207 (in Russian).

7. Krivenko P. V. (1993) Hydration and Dehydration Process of Receiving an Artificial Stone on the Basis of the Alkaline and Silicate Binding. Tsement $=$ Cement, (3), 39-40 (in Russian).
8. Leonovich S. N., Sviridov D. V., Belanovich A. L., Shchukin G. L., Savenka V. P., Karpushenkov S. A. (2012) Prolongation of Working Life of Mortar Mixes. Stroitel'nye Materialy [Construction Materials], (10), 74-77 (in Russian).

9. Savenka V. P., Shchukin G. L., Leonovich S. N. et al. (2012) Method of Obtaining the Hardener for the Concretes and the Mortars. Patent Republic of Belarus No 18077 (in Russian).

10. Betikov I. E., Demidovich B. K. (1992) Raw Mix for Production of Expanded Clay. Patent Soviet Union No 1715750 (in Russian).

11. Samchenko S. V., Krivoborodov Yu. R. (2003) Influence of Dispersion of Special Cement on Structure of the Hardening Stone. Vestnik BGTU im. Shuhova $=$ Bulletin of BSTU named after V. G. Shukhov, (5), 238-240 (in Russian).

12. Krivoborodov Yu. R., Nefed'ev A. P., Kossov D. Yu. Curing of Cement with Metakaolin's Additive. Available at: http://metakaolin.ru/Documents/Tverdenie_tsementa s_dobavkoy_metokaolina.pdf (in Russian).

13. Bezrukova T. F. (1990) Additives in Cellular Concrete. Moscow, VNIIESM. 37 (in Russian).

14. Serdyuk V. R., Vahitov S. G. (1983) Intensification of Structurization and Curing of Cellular Concrete. Promyshlennost' Stroitel'nykh Materialov. Ser. 8: Promyshlennost' Avtoklavnykh Materialov $i$ Mestnykh Vyazhushchikh [Industry of Construction Materials. Seria 8: Industry of Autoclave Materials and Local Knitting]. Moscow, (11), 13-15 (in Russian).

15. Vasilevskaya N. G., Engdzhievskaya I. G., Kalugin I. G. (2011) The Cement Compositions Reinforced by a Disperse Basalt Fiber. Vestnik Tomskogo Gosudarstvennogo Arkhitekturno-Stroitel'nogo Universiteta $=$ Journal of Construction and Architecture, (3), 153-158 (in Russian).

16. Vasilevskaya N. G., Engdzhievskaya I. G., Kalugin I. G. (2010) Management of Cellular Fibrobeton. Izvestiya Vuzov. Stroitel'stvo $=$ News of Higher Education Institutions. Construction, (11-12), 17-20 (in Russian).

Received: 15.11 .2017

Accepted: 12.02.2018

Published online: 29.03.2019 